\section{Letrônicà}

\title{
Memórias do futuro: alteridade do mundo e do sujeito na poesia de Cecília Meireles
}

\section{Memories of the future: world and subject alterity in the poetry of Cecilia Meireles}

Márcia Helena S. Barbosa ${ }^{1}$ Universidade de Passo Fundo (UPF). Passo Fundo, RS, Brasil.

Doutora em Teoria da Literatura pela PUCRS; Professora da Universidade de Passo Fundo (UPF), Membro do Grupo de Pesquisa Estudos de

(UFF).

E-mail: marciabarbosa@via-rs.net
RESUMO: Este estudo examina as relações entre a poesia e o sagrado na obra poética de Cecília Meireles, mostrando que o sujeito lírico, ao perceber a alteridade do mundo, é levado ao encontro de sua própria alteridade, numa busca em que o futuro imaginado confunde-se com as memórias difusas da origem. 0 trabalho, para desenvolver a análise proposta, adota como embasamento teórico as teses de Michel Collot, que se dedica aos estudos de paisagem na literatura e toma como suporte a fenomenologia de Merleau-Ponty e a crítica temática de Jean-Pierre Richard.

Palavras-chave: Estudos de paisagem; Poesia; Alteridade; Estrutura de horizonte; Sagrado.

ABSTRACT: This study examines the relations between poetry and the sacred in the poetic work of Cecilia Meireles, demonstrating that the lyrica subject, by perceiving the alterity of the world, is brought to meet its own alterity, in a search in which the imagined future is intertwined with diffuse memories of the origin. The work, to develop the proposed analysis, adopts as theoretical basis the thesis of Michel Collot, who is dedicated to landscape studies in literature and takes as support Merleau-Ponty's phenomenology and the thematic criticism of Jean-Pierre Richard.

Keywords: Landscape studies; Poetry; Alterity; Horizon structure; Sacred. 
desejo de ver o que não se dá a ver - aquilo que, mesmo pressentido, é invisível - e de dizer o que, embora indizível, continua a prometer-se nas imagens, sussurrando aos ouvidos mais atentos, marca, de forma indelével, a obra poética de Cecília Meireles. Essa vontade promove uma aproximação entre a poesia e o sagrado que é recorrente no conjunto da produção poética da escritora e que evidencia, em seus versos, a alteridade do mundo e do sujeito. A percepção de uma dimensão outra do mundo desaloja o eu lírico e o leva ao encontro de sua própria alteridade, numa busca que aponta para o futuro, mas que tem como fundamento as memórias de uma origem apenas vislumbrada e, simultaneamente, sempre presente.

A abordagem desses tópicos será realizada mediante a análise de poemas reunidos na Poesia completa de Cecília Meireles que tratam dos temas mencionados e que pertencem a livros escritos e publicados em diferentes épocas, dos anos 20 até a morte da autora, em 1964. Para refletir sobre essas temáticas, de forma a demonstrar sua convergência nos textos da escritora, recorre-se às teses de Michel Collot, formuladas no âmbito dos estudos de paisagem na literatura, nos quais o poeta e pesquisador francês vem se destacando. As ideias por ele desenvolvidas, que têm como base a fenomenologia de Merleau-Ponty e a crítica temática de Jean-Pierre Richard, interessam a este trabalho especialmente no que diz respeito aos conceitos de estrutura de horizonte e de referente poético - ambos relacionados à questão da identidade e da alteridade -, bem como à definição dos traços constituintes da poesia e do sagrado que, sendo comuns a ambos, aproximam os dois elementos.

Nos estudos teórico-críticos de Michel Collot, é por meio da noção de paisagem que se esclarece a relação entre estrutura de horizonte e identidade. A paisagem é concebida por Collot (2010) como um dado construído e simbólico, como uma construção da subjetividade, pois a percepção do espaço não se limita à recepção passiva de dados sensoriais, mas pressupõe a organização capaz de lhes dar um sentido. Desse modo, “pode-se dizer [...] que a paisagem, segundo a crítica temática, une estreitamente uma imagem de mundo, uma imagem do eu, e uma construção de palavras"1 (COLLOT, 1997, p. 192). Além disso, Collot (2010; 2012) esclarece que a estrutura de horizonte é um conceito-chave para a teorização da paisagem e da relação que o sujeito estabelece com o espaço, o outro e a linguagem. 0 teórico apresenta as características dessa organização perceptiva, as quais indicam que não há paisagem sem horizonte, tal o elo existente entre ambos. Essas características estão relacionadas às ideias de ponto de vista, de extensão, de parte e de unidade ou conjunto.

A primeira noção é a de que a paisagem é definida do ponto de vista a partir do qual é examinada, ou seja, é sempre vista por alguém de algum lugar e, por essa razão, é que possui um horizonte. A atividade constituinte de um sujeito é condição da existência da paisagem. Collot (cf. 2012, p. 13) afirma que aquele que vê não se situa diante da paisagem numa relação de exterioridade: ela é apenas uma perspectiva cujos contornos se confundem com os do campo visual do sujeito. O estudioso acrescenta, ainda, que a paisagem não é somente vista, mas também habitada e vivida, e que o horizonte é que permite ao sujeito transformá-la em seu território, como espaço ao alcance do olhar e à disposição do corpo. A possibilidade de se investir na paisagem qualquer tipo de conteúdo psicológico é explicado por essa conivência que o olhar e o corpo inteiro mantêm com ela. $\mathrm{O}$ fato de a paisagem refletir os estados de alma é o que leva o teórico a pensar na busca ou eleição de um horizonte privilegiado como uma forma de busca de si mesmo: "Por que preciso de uma paisagem quando procuro reapoderarme de minha própria identidade? Se não é porque, toda consciência sendo

Cf. original: "[...] on peut dire [...] que le paysage, selon la critique thématique, unit étroitement une image du monde, une image du moi, et une construction de mots". (Salvo indicação, todas as traduções do original são nossas.) 
consciência de..., ela pode definir-se apenas por seu horizonte" (COLLOT, 2010, p. 207).

A segunda ideia é a de que o sujeito possui existência somente através de um espaço oferecido ao desdobramento de seus poderes, o que lhe é garantido pela extensão da paisagem, "que o define como ek-sistente sempre à distância de si". Essa extensão favorece uma presença de si que deve ser entendida "como uma maneira de ser 'perto de si do outro lado de si, em uma proximidade inaproximável"', e não como uma identidade já definida e fechada sobre si mesma (COLLOT, 2010, p. 207). O horizonte é, assim, a imagem do futuro. $\mathrm{O}$ teórico resume a correspondência entre horizonte e subjetividade, paisagem e existência, na passagem a seguir:

A distância que me une ao horizonte ao mesmo tempo em que ela dele me separa corresponde à própria estrutura da subjetividade, cujo destino é ter que encontrar-se para além de uma distância sempre mantida de si para si. A dialética do próximo e do longínquo rege tanto a paisagem como a existência; ela possui um significado indissociavelmente espacial ou temporal (COLLOT, 2010, p. 208).

A profundeza do espaço, que corresponde alegoricamente à profundeza do tempo, é a imagem da "amplidão da vida" - "lá, é daqui a pouco ou amanhã" -, fundamental para que a existência possa desabrochar ou arrebatar-se em direção ao futuro (COLLOT, 2010, p. 208).

A terceira noção diz respeito ao aspecto parcial da paisagem. A parte da região que ela oferece ao olhar é determinada pela extensão do campo visual do espectador e pelo relevo do espaço observado. Assim, o ponto de vista adotado exclui as demais perspectivas. Collot $(2010 ; 2012)$ distingue o horizonte externo do horizonte interno: o primeiro é uma linha que circunscreve a paisagem e além da qual mais nada é visível; o segundo é constituído pela existência de partes não visíveis no interior do campo delimitado. Essa limitação da visibilidade faz surgirem lacunas que convertem a paisagem numa estrutura de apelo, isto é, sendo incompleta, a paisagem pede para ser completada pela percepção, e o sujeito, por meio de uma intervenção ativa, pode preencher tais lacunas graças à imaginação, à palavra ou ao movimento. Desse modo, "o horizonte é poético porque é um convite perpétuo para recriar a paisagem", "porque abre nesta uma dimensão de alteridade" (COLLOT, 2010, p.211). Essa alteridade possui um significado intrassubjetivo, pois mobiliza no sujeito as potências da lembrança e da imaginação, e uma dimensão intersubjetiva, porque as falhas no visível são também aquilo que relaciona o campo visual do sujeito com os de outros sujeitos: aquilo que ele não vê é o que pode ser visto pelo Outro. O horizonte torna-se objeto de desejo na medida em que é o lugar do Outro e convida, assim, a explorar outros mundos. Collot (2010, p.212) conclui afirmando que o horizonte é um não lugar, "utopia do desejo", e supõe que é talvez pelo fato de ele ser "um objetivo inacessível" para o movimento que se torna para a fala "um objeto privilegiado: na falta de poder transportar-se até ele, o poeta tentará aproximá-lo por metáforas".

A quarta ideia é a de que a limitação do espaço visível assegura a unidade da paisagem, constituindo-a como uma totalidade coerente, um todo homogêneo. $O$ horizonte funda a coesão da paisagem ao excluir os elementos heterogêneos. Esse enquadramento perceptivo é que faz a paisagem ser percebida como um objeto estético, isto é, ser apreciada em termos de belo ou feio. É também em virtude desse enquadramento que a paisagem apresenta a tensão essencial a qualquer obra de arte, entre o advento de uma forma ou a constituição de uma estrutura e sua abertura a um fundo abissal, ao invisível, tornando-se uma unidade perceptiva e estética, e, ao mesmo tempo, uma unidade de sentido. Portanto, o horizonte, ao opor-se à paisagem, é "o negativo necessário à emergência do positivo". Trata-se de "uma verdadeira estrutura" - e não de um mero componente, entre outros, da paisagem -, "que condiciona a emergência de um 'sentido dos sentidos'” 
(COLLOT, 2010, p. 215). Essa estrutura de horizonte, fazendo da paisagem um conjunto pré-simbólico, permite que nela se esboce um sentido, mas a impede de petrificar-se em um sistema fechado de significados.

Assim, o referente poético, pelo fato de apresentar uma estrutura de horizonte, também revela e faz emergir a alteridade do mundo e do sujeito, além de consistir na base sobre a qual se institui a convergência entre a poesia e o sagrado, entre a experiência poética e a experiência mística. Collot (1989), ao examinar o problema da referência no texto poético, afirma que o mundo ao encontro do qual a poesia nos leva é o desdobramento de uma realidade que se propõe, a cada vez, de maneira diferente à consciência dos sujeitos, e não um objeto exterior sempre igual a si mesmo - ou uma coisa particular que seria possível identificar -, não podendo, assim, ser encarado sob o modo da objetividade e da identidade. 0 mundo não é, mas se "mundifica", como explica o teórico, ao tomar emprestada uma expressão de Heidegger, e a invenção poética responde a essa metamorfose constante da realidade. $O$ poeta é fiel a tal movimento pelo qual o mundo, a todo instante, pode se revelar Outro. Essa modificação permanente, que causa espanto aos olhos, ocorre porque o mundo jamais é dado senão como horizonte de uma visada distinta, por princípio, de qualquer outro ponto de vista possível.

O referente do poema é, portanto, um "universo imaginário", que constitui uma versão singular, uma visão subjetiva do mundo. $O$ fato de que o mundo não é visto senão por um sujeito mostra que a objetividade é que é uma ficção, enquanto que o imaginário é, ao contrário, um instrumento de conhecimento do real. Desse modo, a poesia promove a redefinição do referente, que, nas palavras de Lefebvre citadas por Collot (1989, p.176), "pode ser concebido 'como uma espécie de reservatório contendo a totalidade das experiências que temos do objeto'”2. Dito de outra forma,

Cf original: "La poésie nous invite donc à redefinir le référent que l'on peut concevoir comme une sorte de réservoir contenant la totalité des expériences que nous avons de l'objet"." o referente poético, que inclui em si os aspectos invisíveis do objeto, "é a coisa com todos os seus horizontes possíveis, todas as perspectivas que nós podemos ter sobre ela, e, a partir dela, sobre o mundo"3 (COLLOT, 1989, p.176). A revelação da coisa pressupõe, assim, um encobrimento, pois o horizonte que está implicado em seu aparecer contém, em reserva, a possibilidade de outras aparições. Com base nessas afirmações, pode-se entender a intransitividade da escrita poética como transitividade absoluta: porque não visa a um objeto específico, ela se abre sobre a abertura sem fundo do Ser, sobre um vazio que contém qualquer coisa, e procura dizer, através de suas figuras, um infigurável.

A referência poética é, então, vazia de conteúdo. 0 referente do qual o poema está em busca é inacessível, o horizonte ao qual ele tende está destinado a faltar, e, nesse insucesso, o teórico propõe que se leia uma abordagem da verdade do Ser, que está presente por sua ausência. Se não visasse ao impossível, a uma presença ausente, o poema, assim privado de sua transcendência, não poderia se tornar presente enquanto tal, e seria rebaixado à categoria de um puro e simples objeto. Dessa forma, tal como o horizonte, o referente do poema é, ao mesmo tempo, inatingível e indispensável; "ele é o ponto de fuga em função do qual se organizam e convergem as linhas da paisagem textual"4 (COLLOT, 1989, p.182). Através do apagamento da situação que lhe deu origem, o poema sugere que há em todo evento um fundo insondável que impede de reduzi-lo a uma realidade circunscrita e identificável, ao torná-lo um advento sempre enigmático do mundo. Portanto, o horizonte é, simultaneamente, a fonte infinita da poesia - no que lhe propõe sempre de despercebido a revelar - e o encobrimento

3 Cf original: "Le référent poétique c'est la chose avec tous ses horizons possibles, toutes les perspectives que nous pouvons avoir sur elle, et, à partir d'elle, sur le monde." textuel." 
que lhe interdita o acesso à totalidade do visível. Sendo inesgotável, a coisa está sempre para além do que dela se diz, de modo que o poeta é onipotente para dar à luz relações surpreendentes entre as coisas, por meio de palavras imprevistas, mas impotente para atingir o próprio ser da coisa. Essa incapacidade do poema de coincidir com a coisa faz da referência poética a experiência dolorosa da separação entre palavra e coisa. E uma tensão permanente instaura-se, porque a referência poética não pode abolir completamente tal distância, nem resignar-se a ela.

A poesia tem no mundo a sua pátria, porém precisa exilar-se dele caso queira dizê-lo. Daí advém a decepção, que é a tonalidade afetiva do poema moderno e que dá a medida da decepção ontológica da poesia. É a dedicação do poeta a uma tarefa decepcionante, porque infinita, que torna o mundo ilimitado. Entretanto, talvez seja justamente nesse insucesso em encontrar seu objeto que consista a verdade do poema, pois, conforme explica Collot (1989, p. 184) ao tomar emprestada uma expressão de Francis Ponge, a coisa é reconhecida como tal pelo sentimento que provoca de que "é diferente de seu nome"; ela afirma sua irredutível alteridade na resistência que opõe a qualquer denominação. É por essa razão que o teórico afirma: “Chamar uma coisa por seu nome não é convocá-la a comparecer diante de nós, é fazêla aparecer em sua própria distância, torná-la presente no coração de sua ausência"5 (COLLOT, 1989, p.186). Dessa maneira, é condição para fazerse poeta tomar consciência de que a relação transparente e imediata entre palavras e coisas constitui-se numa ilusão, própria à linguagem "referencial". O poeta precisa reconhecer que está sujeito ao inexprimível, que a linguagem não tem o poder de dizer tudo, que toda referência é incompleta e inadequada. Assim, tendo um referente que não se deixa dizer, o poema, ao final de seu percurso, reencontra sua origem silenciosa: seu horizonte

${ }^{5}$ Cf. original: "Apeller une chose par son nom, ce n'est pas la convoquer à comparaître devant nous, c'est la faire apparaître dans son éloignement même, la rendre presente au coeur de son absence [...]." último é o silêncio. São os brancos que materializam sobre a página esse horizonte de invisibilidade e de indizibilidade; é por seu intermédio que "o poema se comunica com o silêncio interior ao mundo", que ele "diz mais do que as palavras poderiam dizer"6 (COLLOT, 1989, p. 184).

Se o mundo, em sua estrutura de horizonte, é ilimitado - definindo-se por uma constante metamorfose e por uma irredutível alteridade -, o sujeito que nele vive, e que procura dizê-lo ao tomá-lo como referente poético, também apresenta essas características, o que leva Collot a afirmar que, na poesia moderna, o eu lírico é desalojado de uma pura interioridade. 0 teórico, recorrendo ao pensamento de Merleau-Ponty e de Paul Ricoeur, entre outros, considera o sujeito em sua relação constitutiva com um fora, $\mathrm{e}$ não mais em termos de substância, de interioridade e de identidade. Assim, enfatiza a sua ek-sistência, o seu ser no mundo e para o mundo: "É apenas saindo de si que ele coincide consigo mesmo, não como uma identidade, mas como uma ipseidade que, ao invés de excluir, inclui a alteridade, conforme foi bem mostrado por Ricoeur" (COLLOT, 2013, p. 221-224).

Além disso, o teórico mostra que a estrutura de horizonte - elemento comum ao mundo e ao sujeito - é o ponto de convergência entre a poesia e o sagrado. É exatamente em virtude dessa relação constitutiva com um horizonte de invisibilidade e de indizibilidade que a poesia tem a possibilidade de encontrar a experiência mística, disposta a acolher em si o sagrado. A experiência da distância entre aquilo que é dito e o indizível, entre o significado e o não significável, é comum a ambas. 0 sagrado e a poesia "põem em jogo a estrutura de horizonte, a presença e a ausência, o visível e o invisível, o próximo e o distante"7 (COLLOT, 1989, p.185). Se o

${ }^{6}$ Cf. original: "Par ses blancs, le poème comunique avec le silence intérieur au monde, il dit plus que les mots ne sauraient dire [...]."

en la structure d'horizon, la presence et l'absence, le visible et l'invisible, le proche et le lointain [...]" 
sagrado caracteriza-se por sua retração, e só se mostra escondendo-se, a poesia consiste num espaço reservado ao que se reserva, numa abertura que dá à luz a obscuridade do Ser. Devido a essa afinidade de estrutura que as une, a palavra sagrada e a palavra poética estiveram frequentemente ligadas no curso da história, elo que também pode ser percebido na obra, examinada a seguir, de uma das grandes poetas da língua portuguesa.

A poesia de Cecília Meireles manifesta o desejo do eu lírico de acompanhar a incessante metamorfose do mundo e, ao mesmo tempo, aponta os obstáculos que se interpõem à realização dessa vontade. No poema de Mar absoluto intitulado "Noite" (MEIRELES, 1994, p. 335-336), a noite dirige um convite ao sujeito poético, mas logo "se esconde", pois, ao transbordar "por todos os cantos", escapa a qualquer tentativa feita no sentido de abarcá-la. A seguir, o sujeito conclui que não é apenas o mundo, mas também o seu próprio eu que se mostra constante somente em sua variabilidade ou transformação. Dessa forma, ambos, mundo e sujeito, às vezes, são "nenhum” e, em seguida, "tantos!": “Tão perto!/ Tão longe!/ Por onde é o deserto?/ Às vezes,/ responde,/ de perto,/ de longe./ Mas depois/ se esconde./ Somos um/ ou dois?/ Às vezes,/ nenhum./ E em seguida,/ tantos!".

Observar essa relação do sujeito com o mundo é aprofundar-se, na obra da escritora, na negação da objetividade e da transparência como qualidades passíveis de serem atribuídas ao referente poético e à poesia. A existência de um fundo insondável, que requer do poeta uma fidelidade ao movimento constante, à permanente metamorfose do mundo, está presente na poesia de Cecília Meireles, que põe sua atenção sobre a coisa com todos os seus horizontes possíveis, isto é, com todas as suas aparições possíveis, conforme se lê em "Noite" (MEIRELES, 1994, p.335-336). Nesse poema de Mar absoluto, antes comentado, o instante em que se dá o transbordamento da vida é caracterizado como um despertar do qual emerge o invisível: "A vida/ transborda/ por todos os cantos./ Acorda/ com modos/ de puro/ esplendor".

Em “Destino" (MEIRELES, 1994, p. 155-156), texto incluído em Viagem, verifica-se, ainda, a maneira como a obra da autora aborda a perseguição em que se lança a poeta, "pastora de nuvens", atrás de seu "vário rebanho". A dificuldade do ofício assumido por tal pastora reside, em parte, na instabilidade desse gado que ela precisa capturar, reunir - mas que nunca se dá a ver com a mesma forma - e, consequentemente, na inconstância do canto que depende da apreensão de elementos assim tão fugidios e afeitos à dispersão: "Pastora de nuvens, cada luz colore/ meu canto e meu gado de tintas diversas./ Por todos os lados o vento revolve/ os velos instáveis das reses dispersas". O fato de esse rebanho surgir sempre como aparição e não como aparência, de extraviar-se, deve-se ao efeito de deslumbramento que estrelas e luas exercem sobre ele: "Estrelas e luas que jorram deslumbram/ o gado inconstante que se me extravia”.

À instabilidade do rebanho que é perseguido, soma-se a falta de limites, de fixidez e de segurança da campina. A "pastora de nuvens" movimenta-se sobre um prado que também é "móvel", ou sobre uma "planície aérea" e infinita, na qual não existe a possibilidade de evitar os abismos, pois o que essa experiência exige do sujeito é a abertura para o fundo insondável que há em todo evento e que o converte num advento enigmático do mundo:

Pastora de nuvens, fui posta a serviço

Por uma campina tão desamparada

Que não principia nem também termina,

E onde nunca é noite e nunca madrugada.

(Pastores da terra, vós tendes sossego,

Que olhais para o sol e encontrais direção.

Sabeis quando é tarde, sabeis quando é cedo.

Eu, não.) 
Pastora de nuvens, por muito que espere,

Não há quem me explique meu vário rebanho.

Perdida atrás ele na planície aérea,

Não sei se o conduzo, não sei se o acompanho.

(Pastores da terra, que saltais abismos,

nunca entendereis a minha condição.

Pensais que há firmezas, pensais que há limites.

Eu, não.)

(MEIRELES, 1994, p.155).

O mar é um dos elementos que comparecem na obra de Cecília Meireles em suas várias e distintas aparições, convertendo-se num objeto que é dado enquanto horizonte, isto é, como fonte infinita da poesia e, simultaneamente, como encobrimento, ao interditar o acesso à totalidade do visível. Assim, sendo inesgotável, o mar está sempre para além do que dele se diz. Entre suas diversas aparições, está a imagem de um mar identificado como reino, e capaz de possibilitar o vínculo do ser humano, em especial do poeta, com o sagrado em alguns momentos, mesmo num período marcado pela ruptura dessa aliança.

No poema intitulado "Mar absoluto" (MEIRELES, 1994, p. 266-268), e inserido na obra homônima, o mar, que em dado momento corre "como um touro azul por sua própria sombra" e arremete "com bravura contra ninguém", é depois "a pura sombra de si mesmo/ por si mesmo vencido". Além disso, ele é, ao mesmo tempo, "o dançarino e a sua dança", e, se "não precisa do destino fixo da terra", é porque possui "um reino de metamorfose, para experiência”. Assim, por sua capacidade infinita de transformar-se em outro, esse mar comparece aqui como um mar sem fundo, infigurável em sua totalidade. Chama atenção, ainda, a dimensão sobre-humana que, no texto de Cecília Meireles, essa paisagem adquire diante do olhar do sujeito poético. Desvela-se para o eu lírico a "face espantosa" desse mar, que se retrai tão logo é anunciada a sua dispersão no "reino de um outro mar" - o "Mar absoluto".
Em "Êxtase" (MEIRELES, 1994, p.129), texto inserido em Viagem, o "mar noturno" é o lugar "onde se apaga e acende a salvação". No poema de Vaga música intitulado "Em voz baixa" (MEIRELES, 1994, p. 198), por sua vez, o sujeito poético mostra que a sua trajetória é constituída de várias partidas em direção ao sagrado, do qual se aproxima cada vez mais, até o dia em que virá a dispersar-se inteiramente "no indeterminado Deus", da mesma forma que o mar se dissipa, tal qual uma gota, no "Mar absoluto", como ocorre no texto que leva esse título. De acordo com outro poema de Vaga música denominado "Velho estilo" (MEIRELES, 1994, p. 201), esse dia chegará quando o corpo - "mártir" que sempre se sacrificou "para deixar passar as estrelas do espírito" - vier a tornar-se "símbolo, ideia, sonho". Antes desse momento, no entanto, somente o poeta e seus semelhantes compreendem "tudo" o que o corpo já é, a transcendência que já possui "nesta marcha do infinito" e que, posteriormente, será plena. O poeta é aquele que encontra, dentro do tempo, dentro do mundo pelo qual o ser humano está de passagem, elementos que se situam num reino fora do tempo, como se verifica em "Itinerário" (MEIRELES, 1994, p. 247), texto da mesma obra: "Achei lugares serenos/ e aromas de fonte extinta./ Raízes fora do tempo,/ com flores vivas ainda".

Essa experiência parece intensificar-se no poema de Retrato natural intitulado “O enorme vestíbulo" (MEIRELES, 1994, p. 386-388), lugar no qual o eu lírico vai-se "perdendo e libertando/ em pura matéria divina". Porém, a permanência nesse local é provisória, razão pela qual o sujeito poético pede a seu interlocutor: "Deixa-me andar por muito tempo/ neste vosso enorme vestíbulo". Nota-se, ainda, que ele tem acesso restrito a esse lugar, pois chega até a entrada, mas não avança para o interior do recinto. Além disso, ao final dessa experiência, que coincide com os últimos versos do poema, somente o eu lírico retém a lembrança, os rastros daquilo que lhe foi dado viver, como um sinal de distinção e como uma espécie de orientação para a viagem que 
deve realizar nos limites do mundo terreno, antes de alcançar, de uma vez por todas, o infinito: "Entre todos os convidados,/ eu só guardo a sombra da festa: pequena bússola em meus dedos". Em Solombra (MEIRELES, 1994, p.794), o sujeito poético, distinguido que é pela clarividência, também abre "esta porta além do mundo" e, embora não passe para o outro lado, basta-lhe "o umbral, de onde se avista o ponto certo,/ o grande vértice a que sobe o olhar do mundo".

Em situações como essas, a relação de correspondência entre os objetos e as palavras pode ser restaurada, conforme se percebe em $O$ aeronauta (MEIRELES, 1994, p.464), por exemplo. Nesse conjunto de poemas, o próprio eu lírico, enquanto se manteve em contato com as nuvens, caminhando "além da terra", adquiriu outro nome, "indeclinável", diverso daquele que possuía. Esse é o nome compatível com a "essência etérea e clara" que caracteriza o sujeito poético, a despeito do "desgosto de ser criatura" que o acompanha em sua viagem terrena, como se lê em "Vinho" (MEIRELES, 1994, p.133-134), texto incluído em Viagem. Essa situação ambígua do sujeito poético leva-o a falar não apenas de sua aliança com o divino, mas também de sua prisão e de seu desterro, durante os quais mantém "esse apego/ a um deus supremo", como declara no poema de Mar absoluto denominado "Auto-retrato" (MEIRELES, 1994, p. 273). Na condição de exilado, o eu lírico lamenta-se em determinadas passagens, a exemplo do que ocorre no texto de Viagem intitulado "Valsa" (MEIRELES, 1994, p.134): "Coitado de quem pôs sua esperança/ nas praias fora do mundo...". Essa divisão entre o humano e o divino é sempre motivo de decepção e tem como efeito a sensação de desterro. Segundo os versos da escritora brasileira, quando as "noites extensas" são suspensas, ou quando as mãos que esperavam "o amanhecer definitivo" caem "na torrente do tempo", "o broto das palavras" é cortado "rente à boca", como se lê em outro poema de Viagem que recebe o título de "Grilo" (MEIRELES, 1994, p. 134-135).
Constata-se aí que a ruptura da aliança com o sagrado rouba da própria poesia o poder que detinha de dizer as coisas.

A incapacidade do poema de atingir o próprio ser da coisa, ou de coincidir com esta, também é abordada na primeira estrofe de um conjunto incluído em Viagem e denominado "Quadras" (MEIRELES, 1994, p. 156), em que se evidencia o fato de que a canção fica sempre aquém daquilo que o objeto é, ou do segredo que este preserva por ser inesgotável: "Na canção que vai ficando/ já não vai ficando nada:/ é menos do que o perfume/ de uma rosa desfolhada". Na obra de Cecília Meireles, essa separação entre palavra e coisa, que decepciona a poeta, afirma a irredutível alteridade dos objetos que a linguagem poética pretende nomear. Por isso, chamar as coisas por seu nome, para a poesia da autora, é fazê-las aparecer em sua própria distância e tornar presente a sua ausência. Leia-se um fragmento de um poema do mesmo livro intitulado "Cantar":

Cantar de beira de rio:

água que bate na pedra, pedra que não dá resposta.

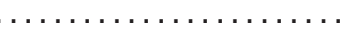

n...................

Pensamento do caminho pensando o rosto da flor que pode vir, mas não vem.

Passam luas - muito longe, estrelas - muito impossíveis, nuvens sem nada, também.

Cantar de beira de rio: o mundo coube nos olhos, todo cheio, mas vazio (MEIRELES, 1994, p. 154) 
Na poesia da escritora, a consciência de que o referente poético não se deixa dizer ou ver completamente leva o poema a reencontrar sua origem, que é o silêncio. Observa-se, ainda, que a menção ao voo das palavras é, na obra em questão, uma forma de evocar o silêncio como parte do poema. Lê-se, no poema 41 de Metal rosicler (MEIRELES, 1994, p. 777): “Cada palavra uma folha/ no lugar certo.// Uma flor de vez em quando/ no ramo aberto.// Um pássaro parecia/ pousado e perto.// Mas não: que ia e vinha o verso/ pelo universo". A mesma ideia comparece no texto de Poemas III intitulado "Voo" (MEIRELES, 1994, p. 1233): "Alheias e nossas/ as palavras voam./ [...]// Oh! alto e baixo/ em círculos e retas/ acima de nós, em redor de nós/ as palavras voam.// E às vezes pousam". Essa alusão ao horizonte de invisibilidade e de indizibilidade dos objetos indica que, se a referência poética não pode abolir completamente a distância que a separa das coisas - uma vez que as palavras são, simultaneamente, "alheias e nossas" e que o seu pouso é raro e sempre incerto -, o poema pode, ao menos, incorporar o indizível, como quem guarda "a sombra da festa" avistada à distância.

A análise demonstra que, na poesia de Cecília Meireles, está bem presente a consciência de que o poema acaba reencontrando seu horizonte último, o silêncio, e de que a alteridade caracteriza tanto o mundo quanto o eu lírico que, para dizê-lo, tem de assimilar a indizibilidade do referente poético. Ao mesmo tempo, o exame até aqui realizado já sugere que, na obra da autora, a poesia e o sagrado aproximam-se, e às vezes confundem-se, em virtude da relação constitutiva que possuem com um horizonte de invisibilidade e de indizibilidade. Entretanto, alguns poemas da escritora evidenciam esse aspecto, em vez de somente sugeri-lo, ao fazerem referência ao sagrado esteja ele aí representado por Deus, pelos deuses ou por uma noção difusa e indefinida - apontando, de modo explícito, para a experiência que supõe: a da distância entre aquilo que é dito e o indizível, entre o significado e o não significável.
Na obra poética de Cecília Meireles, a presença do sagrado não pode ser confirmada pelo olhar. Em Solombra (MEIRELES, 1994, p. 787), o eu lírico chega até o umbral, mas constata que, no "mundo estranho a estas festas humanas" ao qual tem acesso parcial, há um rosto que jamais pode ser visto. Esse mundo, além de invisível, é indizível, pois nunca é completamente alcançável por meio da linguagem. Nele, "as palavras são conchas secas, bradando// a vida, a vida, a vida! e sendo apenas cinza", de modo que o sagrado não apenas não se dá a ver como também mergulha no silêncio, fazendo-se presente sempre como uma ausência: "Pousa// teu nome aqui, na fina pedra do silêncio,/ [...] na água que leva cada encontro para a ausência”. No "Poema da fascinação" (MEIRELES, 1994, p. 933), o primeiro do conjunto que recebe o título significativo de Poema dos poemas, o eu lírico, ao invocar seu interlocutor, chama-o de "Eleito" e emprega o pronome oblíquo "Ti", marca da segunda pessoa do singular, grafando ambos os vocábulos com a inicial maiúscula. Nesse texto, mais uma vez, o sujeito poético procura aproximar-se do sagrado e tem como guia o olhar de um vulto, que o atrai na mesma medida em que se nega, retraindo-se: "Vou a Ti,/ seguindo a luz dos teus olhos [...]/ O teu vulto,/ lá em cima,/ é um palácio branco, a atrair-me.../ Quando chegarei,/ ó Eleito,/ diante de Ti?/ Quando descerrarás/ as tuas portas [...]?".

No "Poema das bênçãos" (MEIRELES, 1994, p.947), que integra a segunda parte do mesmo conjunto de textos, o sujeito poético reafirma a impossibilidade de um acesso completo ao sagrado, quando declara que canta o seu "Eleito", embora tenha de viver, "sempre,/ sem poder conhecê-Lo/ e sem poder encontrá-Lo...". Em "Explicação" (MEIRELES, 1994, p. 236), poema de Vaga música, Deus é o incognoscível que, todavia, é visto como alguém que tudo conhece: "Deus não fala comigo - e eu sei que me conhece". No texto de Poemas III intitulado "Parusia" (MEIRELES, 1994, p.1233), por sua vez, o eu lírico mostra que morrerá sem assistir à chegada de Cristo e que, somente no 
evangelho - "naquele livro dourado" -, o sagrado aparece como "Presença" plena descida do "Mistério". Nos últimos dois versos, o sujeito poético conclui: "Lá eu vi a Presença, a Luz do Céu, a felicidade do mundo.// O resto aparece apenas na minha alma”. Evidencia-se aí a consciência de que a alma capta o invisível e o impronunciável, justamente porque integra à percepção que tem do sagrado o horizonte de invisibilidade e de indizibilidade que lhe é inseparável.

O poema de Vaga música que recebe o título de "Velho estilo" (MEIRELES, 1994, p. 202), antes comentado, reitera essa noção. Nesse texto, o eu lírico dirige-se a seu interlocutor, que é inatingível, utilizando a expressão "Coisa que passas" e perguntando-lhe qual é o seu nome, ao mesmo tempo em que afirma: "Tua presença nalguma parte/ é já sinal da tua partida”. Ao final, o poema aponta para o único vestígio desse ser que permanece depois que "tudo se apaga". Esse rastro é a expectativa ou o desejo de ter ao alcance das mãos aquele que se ausenta: "No ardente nível desta experiência,/ [...] tudo se apaga, preso em sigilos:/ mas no desenho do último gesto,// há mãos de amor para a tua ausência". Assim, o sagrado, tal como o referente poético, é um vazio que pode guardar tudo, conforme se verifica pela pergunta que o eu lírico faz a seu interlocutor em "Rimance" (MEIRELES, 1994, p. 250251), poema da mesma obra: "Por que me destes um corpo,/ se estava tão descansada,/ nisso que é talvez o Todo,/ mas parece tanto o Nada?".

Esse encontro entre as experiências poética e mística é abordado de diversas maneiras e com distintas modulações na poesia de Cecília Meireles. Se, em um poema anteriormente examinado, a poetisa é a "pastora de nuvens" que tenta reunir um gado sempre ameaçado de extravio, no texto de Poemas III intitulado "Meu pasto é depois do dia, dos horizontes" (MEIRELES, 1994, p. 1208-1209), ela assume a condição de rebanho que pasta numa "grande mão invisível" e "eterna". Em outra ocasião, a proximidade entre essas duas experiências é tal que a ligação entre a alma e o universo, já desfeita, é definida como "um poema" que "parecia perfeito". Leia-se um fragmento do poema 14 de Metal rosicler (MEIRELES, 1994, p. 778-779): "Houve um poema,/ entre a alma e o universo./ Não há mais./ [...]// Houve um poema:/ parecia perfeito./ Cada palavra em seu lugar,/ como as pétalas nas flores". Esse poema, que tem como "um rastro de sua cor" o "coral do horizonte", e do qual o eu lírico "já" não se lembra e "ainda" se lembra, parece fazer eco à cantiga que o sujeito poético deseja cantar, mas não consegue, aludida no texto de Mar absoluto intitulado "Inibição" (MEIRELES, 1994, p. 313-314), o que talvez se possa interpretar como uma falha da poesia em seu intento de religar o mundo humano ao sagrado.

Se essa cantiga não se concretiza, de acordo com as hipóteses do eu lírico, porque é tardia ou precoce, é sinal de que ela fala - por meio de uma voz que não soa - da aliança quebrada e ainda não restaurada, ou só provisoriamente restabelecida. E talvez por essa mesma razão, em "Diálogo" (MEIRELES, 1994, p. 138), poema incluído em Viagem, o eu lírico defina suas palavras como "a metade de um diálogo obscuro/ continuando através de séculos impossíveis". Assim, no momento presente, o sujeito poético não poderia ser feliz nem mesmo com a "glória", que tornaria grande parte dos seres humanos satisfeitos. Essa impossibilidade deve-se ao fato de que ele, como demonstra o poema da mesma obra intitulado "Transeunte" (MEIRELES, 1994, p. 329), está voltado para o passado e, simultaneamente, para o futuro, ou seja para o período em que a sua unidade com o divino ainda não havia sido destruída e para o instante em que essa mesma unidade voltará a existir. Desse modo, o sujeito poético é aquele que, tendo "intuições" e "memória", vive "construindo apenas Deus...".

Se o poema que ligava a alma ao universo esvaiu-se, o que está "brotando pela noite lisa", como se afirma em "Embalo" (MEIRELES, 1994, p, 204), texto de Vaga música, são "as lágrimas de uma canção/ pelo que não se realiza", restando à poeta dizer a saudade daquilo que foi e a espera por aquilo 
que virá. Todo ser humano possui uma alma que é divina e um corpo que a mantém durante sua passagem pelo mundo terreno, permanecendo, no decorrer dessa viagem, entre "estandartes do vento" e "sepulcros fechados", como se verifica no poema do mesmo livro denominado "Canção quase inquieta" (MEIRELES, 1994, p. 187). Todavia, é o poeta que experimenta com mais intensidade essa condição ambígua - "E eu me partindo, dentro de mim" -, ao esforçar-se "para estar no mesmo momento/ de ambos os lados". Esse lugar intermediário ocupado pelo poeta num sentido geral é, portanto, a sua marca e, acima de tudo, o traço que define, especificamente, uma poeta: Cecília Meireles. Leia-se a última estrofe do poema de Mar absoluto, antes comentado, que recebe o título de "Noite" (MEIRELES, 1994, p. 336), no qual o eu lírico feminino indaga a Deus sobre o seu estado: "Pergunto a Deus se estou viva,/ se estou sonhando ou acordada./ Lábio de Deus! Sensitiva/ tocada".

Dessa forma, no poema da mesma obra denominado "Interpretação" (MEIRELES, 1994, p.307), pode-se ver o ato de interpretar como uma menção à condição do poeta, que, embora vivendo entre os demais seres humanos, desempenha outro papel ou tem acesso a outra existência: “[...] meu mundo é feito de outra vida" / Talvez nós não sejamos nós". Esse mesmo ato, entretanto, parece ter também outro significado, pois a interpretação é algo que se deseja ver realizado pelas palavras, uma vez que a alma do poeta sabe mais do que a linguagem tem capacidade de dizer: "As palavras aí estão, uma por uma:/ porém minha alma sabe mais". Assim, o poema é um convite feito aos lábios para que eles verbalizem a incapacidade e, ao mesmo tempo, o desejo da poesia de falar daquilo que, mesmo lembrado ou intuído, nunca é inteiramente atingido, o ser das coisas e o sagrado. O verbo "falar" no imperativo - "falai" -, acompanhado do ponto de exclamação nos dois versos em que se faz presente, figura, então, como uma interpelação da poeta ao "lábio fatigado de ais", logo a si mesma, para que interprete o horizonte de indizibilidade que cerca tanto o seu rebanho, a matéria poética, como o seu pasto, isto é, a percepção do sagrado que a alimenta e que, simultaneamente, provoca nela uma fome que não pode ser saciada.

No poema de Viagem intitulado "Personagem" (MEIRELES, 1994, p.164-165), afirma-se que a "arte de amar é exatamente/ a de ser poeta". Pode-se pensar, com base nessa frase e nos demais textos comentados, que o poeta, ao lidar com um referente sempre cercado pelo silêncio e pela invisibilidade, domina uma arte que coincide, em sua natureza, com a arte de interpretar o sagrado. Quando declara seu amor por um interlocutor "sem forma e sem nome", que existe "silencioso, obscuro e disperso", o eu lírico explica que, para pensar nesse ser não nomeado, basta-lhe "o próprio amor" que sente por ele. É justamente essa falta, essa ausência do referente poético e do elemento divino que mantém a busca da poeta: "[...] eu procuro o que não se avista". Assim, ao visar à transcendência, isto é, ao procurar por algo que é inacessível enquanto totalidade, mas imprescindível, que está perto e longe de si, a poeta vê-se sempre diante de um abismo: "E, nesse abismo do meu sonho,/ alheia a todo outro desejo,/ me decomponho e recomponho...". A decomposição ou divisão que experimenta advém de sua dupla condição, do fato de estabelecer vínculos com o divino, mesmo sendo criatura humana, mas também deriva da estrutura da poesia e do sagrado, uma vez que, por meio de ambos, a poeta reconquista sua unidade ao mesmo tempo em que se perde e se dissipa no todo.

Muitos desses aspectos são explicitados e/ou desenvolvidos em "Recitativo próximo a um poeta morto", escrito por ocasião da morte de Jorge de Lima, que integra Poemas III e no qual o eu lírico afirma: "Que é o poeta/ senão o burlador das fronteiras da vida [...]?”. O poeta é capaz de burlar essas fronteiras, "porque já não é humano, e ainda é humano", porque vê e ouve mais do que todos os outros seres humanos, mas não pode ver e ouvir tudo, porque tem acesso limitado ao ser das coisas e ao sagrado: 
Jaz um Poeta:

- o ouvido que melhor ouve o apagado e esquecido,

e recolhe sua informulada queixa e seu cântico longínquo;

- o olho que mais longe avista,

até onde as formas ainda são simples esquemas,

onde tudo que parece o mais simples

se desdobra e entrelaça em trama profunda

Sem ser Deus, nem profeta, nem sábio,

mas tudo isso, imperfeitamente e amargamente,

porque é apenas um Poeta.

(MEIRELES, 1994, p.1065-1067).

Esse ser "múltiplo, complexo,/ contraditório,/ solitário e plural", esse "aprendiz de Criador", "demiurgo" a balançar-se "em aéreos fios de Efêmero e Eterno", possui uma voz em que se reconhecem os mesmos atributos que o distinguem e que, sendo fragmento, mas ainda assim fragmento de uma totalidade, é, ela própria, reverberação da "voz única" e una de que faz parte. Essa voz também aponta para a reunião entre poesia e sagrado na obra de Cecília Meireles:

Essa voz que era sua e não era sua...

Correspondência de mil vozes,

trecho de uma voz única,

uma só linguagem,

traduzida em mil idiomas, em mil imagens,

toda fragmentada, nessa queda violenta do mistério,

e, no entanto, dúctil,

com uma unidade antiga e mágica,

acima, além de seu poder e conhecimento:

sua voz - esforçado eco.

(MEIRELES, 1994, p. 1067-1068).

A análise demonstra que é recorrente, na obra de Cecília Meireles, a abordagem dessa afinidade de estrutura entre poesia e sagrado e que a atenção a tal temática evidencia o modo como o eu lírico posiciona-se e constitui-se em relação às diversas aparições desses elementos Diante de uma ausência que se faz presente, que se promete nas imagens e que pede para ser dita, embora nunca se dê a ver inteiramente e seja indizível, o sujeito poético empenha-se em ver o invisível e em dizer o silêncio. Assim, ele assume a dupla condição dos seres que, em instantes breves e fugidios, acercam-se da transcendência, mas logo a perdem de vista e precisam prosseguir na sua busca. Essa situação ambígua define o "embalo", a coreografia executada pelo eu lírico e assim denominada por ele. Ao situar sua poesia nessa fronteira entre o humano e o divino, a autora convertese em uma "pastora de nuvens", exibindo uma distinção que implica o acesso a um reino "fora do tempo" e, simultaneamente, a consciência de uma permanente instabilidade, gerada pela convivência com a perda e a precariedade que caracterizam a existência humana.

"Sensitiva", a poeta que fala pela voz do eu lírico atende às solicitações da paisagem, que, em virtude de sua estrutura de horizonte - e, consequentemente, de suas lacunas -, converte-se em uma estrutura de apelo. Desse modo, o sujeito lírico identifica as manifestações do sagrado que conferem a este mundo, tomado como referente poético na obra analisada, uma dimensão de alteridade. E é essa mesma dimensão que mobiliza no eu lírico as potências da imaginação e da lembrança, possibilitando que ele veja a si mesmo como um outro e que estenda essa percepção a todos os seres humanos, como indica o verso já citado: "Talvez nós não sejamos nós". Além disso, o encontro com o divino, visto como um reencontro, é uma promessa de unidade para o sujeito lírico, esse ser "partido", que em sua passagem pela vida precisa se esforçar, de acordo os versos comentados anteriormente, "para estar no mesmo momento/ de ambos os lados". Todos esses fatores levam a concluir que, na obra poética de Cecília Meireles, a poesia e o sagrado aproximam-se porque apresentam uma estrutura semelhante e, também, porque o poeta é concebido pela autora como um 
demiurgo - uma criatura que, a despeito de sua condição humana, possui vínculos com o divino.

\section{Referências}

COLLOT, Michel. La poésie moderne et la structure d'horizont. Paris: PUF, 1989.

COLLOT, Michel. Les enjeux du paysage. Bruxelles: Ousia, 1997.

COLLOT, Michel. Do horizonte da paisagem ao horizonte dos poetas. Trad. Eva Nunes Chatel. In: ALVES, Ida; FEITOSA, Marcia Manir Miguel (Org.). Literatura e paisagem: perspectivas e diálogos. Niterói: Ed. da UFF, 2010. p. 205-217.

COLLOT, Michel. Pontos de vista sobre a percepção de paisagens. Trad. Denise Grimm. In: NEGREIROS, Carmem; ALVES, Ida; LEMOS, Masé (Org.). Literatura e paisagem em diálogo. [S.l.]: Edições Macunaíma, 2012. p. 11-28.

COLLOT, Michel. O sujeito lírico fora de si. Trad. Zênia de Faria e Patrícia Souza Silva Cesaro. Signótica, Goiânia, v. 25, p. 221-241, 2013.

MEIRELES, Cecília. Poesia completa. Rio de Janeiro: Nova Aguilar, 1994.

Recebido em 20/02/2018.

Aceito em 01/05/2018. 